\title{
Targeting Telomerase and Topoisomerase-II by Natural Moieties: An Anti-Cancer Approach
}

\author{
Vivek Kumar Garg ${ }^{1}$, Dharam Bir Kashyap² and Hardeep Singh Tuli ${ }^{3 *}$ \\ ${ }^{1}$ Department of Biochemistry, Government Medical College and Hospital (GMCH), India \\ ${ }^{2}$ Department of Histopathology, Postgraduate Institute of Medical Education and Research (PGIMER), India \\ ${ }^{3}$ Department of Biotechnology, MMUniversity, India \\ *Corresponding author: Hardeep Singh Tuli, Assistant Professor,Department of Biotechnology, M.M. University, Mulana, Ambala, Haryana, India
}

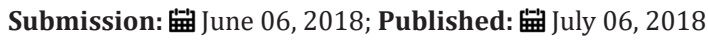

Keywords:Telomerase; Topoisomerase; Telomeres; Quercetin

\section{Short Communication}

One of the fundamental characteristic of tumor cell is to maintain the telomere length for continues progressive growth and survival. For the same, tumor cell has elevated levels of telomerase enzyme[1]. Telomerase is an unusual enzyme that acts on parts of chromosomes known as telomeres. Telomerase is a ribonucleoprotein and expressed in approximately $85 \%$ of different human cancers[2]. There is strong evidence for the existence of an important relationship between telomeres, telomerase and cancer [3]. Normal human cells progressively lose telomeres with each cell division until a few short telomeres become uncapped leading to a growth arrest, known as replicative aging. This phenomenon is totally absent in the cancer and cancer cells are adapted to have higher levels of telomerase enzyme which results in uncontrolled cell division. Attempts have also been made to develop telomere length-and telomerase-based diagnostic tools and anticancer therapeutics [4]. Secondly, topoisomerase-II (Topo-II) also attracts researchers that could be another target for anti-cancer therapy. Topo-II itself required for DNA replication, transcription and chromosome segregation. Because Topo-II is crucial for genomic integrity, interference in its activity might be an effective strategy for cancer chemotherapy. Although there are etoposide and doxorubicin anti-cancer drugs for Topo-II but development of therapy resistance restricts their ability. The phytochemicals including flavonoids and xanthonoid are known to possess strong cancer inhibitory action due to their action against telomerase and Topo-II. There is plenty ofwork available which is supporting the fact. For instance, Tawani and Kumar, found the role of quercetin against human telomerase enzyme[5].Study on MGC-803 and SGC-7901 human gastric carcinoma cells explored that Gambogic acid (GA) suppresses telomerase activity and telomerase reverse transcriptase (TERT) mRNA level via down-regulation of c-Myc oncogene expression[6]. Further, Wu et al. [7] reported GA mediated inhibition of human lung carcinoma growth using of SPC-A1 cell and xenograft nude mice model due to negatively regulation of telomerase/hTERT expression.Similarly, couple of in-vivo and in-vitro studies has been carried out on human hepatoma SMMC7721 cells and demonstrated dose and time dependent inhibitory effect of GA on telomerase activity[8,9].Moreover, GA was also found to modulate the post-translational modifications of hTERT via Aktsignalling dependent mechanisms[10]. Genistein (GEN) induces growth arrest in association with telomerase inhibition in brain tumor cells via the suppression of TR- and TERT mRNA[11]. In addition,Cantero et al. [12] performed a comparative study in Chinese hamster ovary AA8 cells and showed that the flavonoids, luteolin and quercetin are topo II inhibitors.GEN inhibition of Topo-II expression through the regulation of Specificity protein 1 and Specificity protein 3 and HeLa cell apoptosis[13].Hence after looking at the data author(s) would like to divert researcher toward flavonoid's anti-cancer activity mediated through telomerase and Topo-II inhibition.

\section{Acknowledgement}

The authors fully acknowledge Department of Histopathology, Postgraduate Institute of Medical Education and Research (PGIMER), Chandigarh and MM University, Mulana, Ambala, Haryana, India, for providing the requisite facility for the study.

\section{References}

1. Shay JW, Wright WE (2011) Role of telomeres and telomerase in cancer. Semin Cancer Biol 21(6): 349-353.

2. Cong YS, Wright WE, Shay JW (2002) Human telomerase and its regulation. Microbiol Mol Biol Rev 66(3):407-425. 
3. Goel N, Karir P, Garg VK (2017) Role of DNA methylation in human age prediction. Mech Ageing Dev 166: 33-41.

4. Jafri MA, Ansari SA, Alqahtani MH, Shay JW (2016) Roles of telomeres and telomerase in cancer and advances in telomerase-targeted therapies. Genome Med 8(1): 69.

5. Tawani A, Kumar A (2015) Structural insight into the interaction of flavonoids with human telomeric sequence. Sci Rep 5(1): 17574.

6. Yu J, Guo QL, You QD, Lin S Sen, Li Z, et al. (2006) Repression of telomerase reverse transcriptase mRNA and hTERT promoter by gambogic acid in human gastric carcinoma cells. Cancer Chemother Pharmacol 58(4): 434-443

7. Wu ZQ, Guo QL, You QD, Zhao L, Gu HY (2004) Gambogic acid inhibits proliferation of human lung carcinoma SPC-A1 cells in vivo and in vitro and represses telomerase activity and telomerase reverse transcriptase mRNA expression in the cells. Biol Pharm Bull 27(11): 1769-1774.

8. Guo QL, You QD, Wu ZQ Yuan ST, Zhao L (2004) General gambogic acids inhibited growth of human hepatoma SMMC-7721 cells in vitro and in nude mice. Acta Pharmacol Sin 25(6): 769-774.
9. Du QY, Wang XB, Chen XJ, Zheng W, Wang SQ (2003) Antitumor mechanism of antisense cantide targeting human telomerase reverse transcriptase. World J Gastroenterol 9(9): 2030-2035.

10.Zhao Q Yang Y, Yu J, You QD, Zeng S, et al. (2008) Post transcriptional regulation of the telomerase hTERT by gambogic acid in human gastric carcinoma 823 cells. Cancer Lett 262(2): 223-231.

11. Khaw AK, Yong JWY, Kalthur G, Hande MP (2012) Genistein induces growth arrest and suppresses telomerase activity in brain tumor cells. Genes Chromosom Cancer 51(10): 961-974.

12. Cantero G, Campanella C, Mateos S, Cortés F (2006) Topoisomerase II inhibition and high yield of endoreduplication induced by the flavonoids luteolin and quercetin. Mutagenesis 21(5): 321-235

13. Zhou N, Yan Y, Li W, Wang Y, Zheng L, et al. (2009) Genistein inhibition of topoisomerase II apha expression participated by Sp1 and Sp3 in HeLa cell. Int J Mol Sci 10(7): 3255-3268.
Creative Commons Attribution 4.0 International License

For possible submissions Click Here
Submit Article

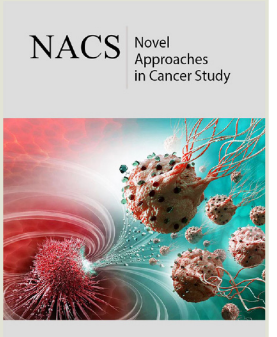

\section{Novel Approaches in Cancer Study}

\section{Benefits of Publishing with us}

- High-level peer review and editorial services

- Freely accessible online immediately upon publication

- Authors retain the copyright to their work

- Licensing it under a Creative Commons license

- Visibility through different online platforms 